\title{
CAMEL Analysis on Performance of ASEAN Public Listed Banks
}

\author{
Rossazana Ab-Rahim ${ }^{1}$, Norlina Kadri ${ }^{1}$, Amy-Chin Ee-Ling $^{1}$, Abdul Alim Dee ${ }^{1}$ \\ ${ }^{1}$ Faculty of Economics and Business, Universiti Malaysia Sarawak, 94300 Kota Samarahan, Sarawak, Malaysia \\ Correspondence: Rossazana Ab-Rahim, Faculty of Economics and Business, Universiti Malaysia Sarawak, 94300 \\ Kota Samarahan, Sarawak, Malaysia.
}

Received: February 7, 2018

Accepted: March 2, $2018 \quad$ Online Published: March 12, 2018

doi:10.5539/ibr.v11n4p96

URL: https://doi.org/10.5539/ibr.v11n4p96

\begin{abstract}
The study is conducted to measure the performance of public listed banks in five ASEAN countries. This study covers 63 public listed banks from Malaysia, Singapore, Thailand, and the Philippines over the period of 1997 to 2011. The CAMEL analysis which is based on Capital Adequacy, Asset Quality, Management Efficiency, Earning Quality, and Liquidity is employed in this study. The objectives of the study are to measure the performance of public listed banks as well as to compare the performance across countries. The results of the CAMEL analysis show that Singaporean public listed banks are the top performer as compared to their counterparts. Next, the comprehensive results reveal that Public Bank in Malaysia, United Overseas Bank in Singapore, Bank ArthaGraha in Indonesia, Bank of Ayudhya in Thailand and Union Bank of the Philippines are the top performed banks.
\end{abstract}

Keywords: CAMEL, financial ratios, banking, ASEAN

\section{Introduction}

Governor of Central Bank Malaysia has encouraged ASEAN for moving closer towards the regional integration among countries to become a single regional common market by the year of 2015 under the ASEAN Economic Community (AEC) ${ }^{1}$. The ASEAN banks play an important role to support and foster the financial integration in this region, such as in mobilizing, allocating, and investing the savings of the society. The strong growth of ASEAN financial institutions are driven by the development of business fundamental and the increasing competitiveness of financial institutions in this region. Therefore, the ASEAN banking contributes a large part to the regional integration as it increases the corporation among ASEAN countries especially in the financial perspective. Hence, it is essential to have a comprehensive insight on the performance of banking industry as the bank performance has a significant influence on the investment, firm, growth, industrial expansion, and economic development of a country.

Concerning the banking reform history and the recent banking integration, this provides a unique feature to the ASEAN banking market for this study to embark upon the issue of ASEAN banking performance. In addition, ASEAN countries are also moving toward to strengthen their economic and financial ties. According to Phar (2010), the emerging economies in ASEAN countries will attract global investment banks to strengthen their financial position in this region. Besides, the ASEAN banking performance is relatively important in this region in order to attract international and domestic investors to invest in their institutions. Therefore, this study provides important information to understand the performance and efficiency of banking industry in particular, the ASEAN region with the increasing of contestable international market.

In conjunction to that, this study attempts to evaluate the performance of public listed banks in ASEAN region, specifically by in five major ASEAN nations, namely Malaysia, Singapore, Thailand, Indonesia, and the Philippines, which are also known as ASEAN-5. Being among the fast growing emerging countries and share similar social and economics characteristics (Echchabi,A. 2013), these countries are chosen for this study. Despite the fact that the development of financial sector is the key sector to ensure sustain economic growth in

\footnotetext{
${ }^{1} \mathrm{AEC}$ envisages the key characteristics such as a single market and production base, a highly competitive economic region, a region of equitable economic development, and a region fully integrated into the global economy.
} 
developing countries, Mugume (2007) stated that there are limited studies conducted to measure the banking efficiency in developing countries as compared to developed countries.

During the outbreak of the Asian financial crisis in 1997, the currencies constantly depreciate against US dollar, the amount of unhedged borrowings as well as non-performing loans in the ASEAN countries were mounted. The banks in ASEAN region were exposed to high level of losses and bankruptcy, which had caused ASEAN economies to be mauled severely. During the post-period of the Asian Financial Crisis in 1997/98, the crisis-affected countries have implemented efforts of restructuring process and reforms in order to recover and sustain their banking system from continuing deteriorated. After the crisis, banks regulators implemented several measures to reform the banking system with the aim of providing efficient banking services to the economy on a sustainable basis (Garcia, 1997). According to Barry et al. (2010), the bank restructuring program took place instantly after the crisis in 1997 until the early of 2000s. Besides, the countries in ASEAN region also continuing with consolidation, merger, and acquisition process of local banks as well as begin to open the banking sector for the entry of foreign banks. Despite several studies has been conducted to examine the relationship between foreign bank entry and efficiency in developing countries, as stated by Claessens, Demirguc-Kunt, and Huizinga (2001), Fries and Taci (2002), and Bonin, Hasan and Wachtel (2005), the studies however provide mixed results.

There is growing number of Asian banks becoming public listed and the increasing of market capitalization of Asian financial institution (Wyman, 2012). Hence this study is important that it will contribute towards the regional economic as well as to further enhance and achieve the regional integration. Nonetheless, there are streams of studies on the banking performance of developed economics, especially from the US (Besar, 2011). This paper is organized as follows; next section reviews the theoretical motivation and existing empirical studies to embark upon the issue of banking performance. Next section, discusses on data and methodology, follows by the interpretation of results and discussion while conclusion in the last section.

\section{Literature Review}

Financial statement analysis is widely applied by different interested groups such as investors, managers, and creditors to measure the historical results, current financial position as well as to predict the future financial performance of the banks; hence, the financial management theory is applied in this study. The theory refers to the financial statement analysis as a process of assessing the relationship between the financial statement's component parts in order to get a better understanding of the performance and the position of the firm (Khan and Jane, 2007). Financial statements are commonly analyzed by using the ratio analysis method. The ratio analysis is the use of ratio to interpret the financial statements thereby the strength and weakness of the company as well as it's historical, current and future financial state can be determined (Bhatawdka, 2010). In spite of the size, the ratio analysis can also relate and examine the risk and return of the company in the industry. In addition, the ratio analysis can make the analyzed financial results comparable as to identify the deficiency and take the corrective actions to solve the problem. The comparison can be made in two ways which are the comparison with historical result (trend analysis) and with other competitors in the same business line or industry average. Generally, the financial ratio analysis provides information about a bank's performance on comparative basis and allows the conclusion about the bank performance to derive.

Existing studies on operating performance of banks had tended to employ CAMEL analysis and financial ratios. CAMEL analysis applies financial ratios in evaluating the banking operations based on five dimensions include capital adequacy, asset quality, management efficiency, earnings quality and liquidity. The ratios based on CAMEL framework are able to provide a comprehensive view of banks performance (Nimalathasan, 2008); this performance evaluation can be measured from various aspects which include costs, revenue and profit (Johnes, Izzeldin and Pappas, 2009); it can be calculated and interpreted easily (Hassan and Bashir, 2003); it allows comparison between banks and serves as the benchmark which is generally the average of the industry sectors (Halkos and Salamouris, 2004). ${ }^{2}$

Existing studies on the CAMEL performance in Asian banking sector cover Nepal, Taiwan, Japan, and India. For instance, Jha and Hui (2012) evaluate the financial performance comparison of commercial banks with different ownership structured in Nepal from period of 2005 to 2010. Moreover, the results estimate the return on assets is significantly influenced by the interest expenses to total loan, net interest margin and capital adequacy ratio whereas the return on equity is significantly influenced by the interest expenses total loan, net interest

\footnotetext{
${ }^{2}$ However, there are few drawback of the CAMEL analysis that is there is no any criteria to select a ratio that is acceptable by all interested parties and the ratios calculated from the information in financial statement might either be simplified or added and it might not meet the needs of the users (Ho and Zhu, 2004).
} 
expenses to total loan, net interest margin and capital adequacy ratio. Next, studies on Indian banking sector are contributed by Kumar,S.\& Gulati. (2008), Prasad and Ravinder (2012), and Reddy (2012). Kumar et al. (2008) find out that the private banks are more soundness than the public banks; the results also show that the private banks move faster towards convergence as they grow at a faster pace than the public banks. In contrary, Prasad (2012) states that the performance of public banks and private banks is indifference. Reddy (2012) discovers that the performance of public banks has significantly improved and it reflects the positive impact of the financial reforms from interest rate liberalization, directed credit and investment rationalization as well as the increase of the competition. All the mentioned studies utilize CAMEL method to estimate the performance of banks.

Huang, Wen, and $\mathrm{Yu}$ (2012) examine the financial determinants of bank performance in Taiwan from the period of 2005-2007 (pre-crisis period) and during 2008-2010 (post-crisis period). The findings show that the relationship between the return on assets and certain CAMEL ratios remain strong. Moreover, in terms of asset quality, it shows that there is high protection against external shocks during the pre- and post- crisis period.

Next, Said and Tumin (2011) utilize the return on average assets (ROAA) and return on average equity (ROAE) as the proxy to examine the performance of commercial banks in Malaysia and China from 2001-2007. The findings imply that the financial ratios have different impact on the performance of banks in both countries except for capital and credit ratios. It shows that the bank performance in China tends to be influenced by the operating ratios but there is no significant influence on the bank performance in Malaysia.

As far as this study is concerned, there is no existing study on estimating the financial performance of ASEAN banking sector, thus this study attempts to fill the gap in the existing literature. Existing studies such as Karim (2001), Sufian and Habibullah (2009), and Chan and Karim (2011), tend to confine their analysis on the efficiency performance of ASEAN banking, specifically in Indonesia, Malaysia, Philippines, and Thailand, or also known as the ASEAN-4. Mogid, Tahir, and Haron (2012), however have extended their studies to another four additional countries namely Singapore, Cambodia, Brunei, and Vietnam.

Some of the studies apply stochastic frontier approach to evaluate the bank efficiencies of different ASEAN countries. For instance, Karim (2001) evaluate the bank efficiency of ASEAN-4 from 1989 to 1996. The results show that there are significant differences in efficiency scores among the banks in the four selected countries. Besides, the results also show that higher cost efficiency enjoyed by larger banks as compared to smaller banks. In general, study indicates the ASEAN banks benefit from the increasing returns to scale. Next, the study of Chan and Karim (2011) evaluate the efficiency of foreign banks from the ASEAN-4 countries from 2001 to 2007. Moreover, the results indicate that the foreign banks from developed countries are more efficient than those in the developing countries. The foreign banks in Malaysia were found to be the most profit and cost efficient while the foreign banks in Indonesia has the least. The study also suggested that in order to attract more foreign banks into ASEAN region, the banking sector should be liberalized to enhance the competitiveness of foreign and local banks which lead to the higher banking efficiency in ASEAN.

On the other hand, Sufian and Habibullah (2009) measures the performance of ASEAN-4 banking sectors by using Data Envelopment Analysis (DEA) from the period 1999 to 2005. The study reveals that based on revenue approach, the estimated bank technical efficiency is consistently higher as compared to the intermediation approach. Besides, the results also specify that the banks tend to be inefficient in a more concentrated market. Nevertheless, when the study controls for the countries which undertake IMF program, it has shown that the concentration ratio has positive relationship with the level of bank efficiency. In general during the post crisis period, the higher concentrated banking market that undertakes the IMF program has greater efficiency in their intermediation function.

Mongid et al. (2012) extend their scope of studies to Singapore, Cambodia, Brunei, and Vietnam. In their study, they examine whether the inefficiency of banks is related to its risk taking and capital position in six ASEAN countries (Malaysia, Indonesia, Thailand, the Philippines, Singapore, Cambodia, Brunei and Vietnam) from the period of 2003 to 2008 by using accounting ratios. Throughout the study, it is found that, the inefficiency equation show CAP and SIZE negatively related to inefficiency while RISK is insignificant. In the risk equation, RISK has negative relationship with CAP and INEFF. Nevertheless in the capital equation, CAP negatively related to RISK but not INEFF.

Other than that, Tahir, Moghid, and Haron (2012) have also studied the determinants of cost inefficiency in commercial banks by using the SFA approach and Tobit regression analysis. Tobit regression analysis is used to determine the estimated cost inefficiencies on bank specific characteristics (size, loan to total asset, equity to total asset and personnel expenses to total expenses) and environmental variables (corruption, economic growth and economic freedom). The first finding show that the average bank cost inefficiency during the period of study is around $33 \%$ of the observed total costs. Singapore's banks show the lowest cost inefficiency as compared with 
the banks of other ASEAN countries. The second finding identifies the bank specific variables and economic growth as important determinants in influencing the bank cost inefficiencies. Although the influences of corruption and economic freedom are evident, it only limited to some extent.

There is limited of studies that measure the performance of ASEAN banking (such as Tahir, 1999; Karim, 2001; Sufian and Habibullah, 2009 and Chan and Karim, 2011). Thus, this study is implemented to fill the gap in the existing literature. The CAMEL Analysis, which is useful in providing private supervisory information to measure and monitor the bank performance, is applied in this study to evaluate the performance of public listed banks in the five selected ASEAN countries.

\section{Data and Methodology}

In order to provide an insight of ASEAN banking performance, the set of annual data used in this study covers the period from 1997 to 2011 , by capturing the Asian financial crisis in 1997 as well as the global financial crisis in 2008. A total of 63 public listed banks are chosen among the five ASEAN countries as which 10 listed banks from Malaysia, 3 listed banks from Singapore, 10 listed banks from Thailand, 28 listed banks for Indonesia, and 12 listed banks for the Philippines. The set of data applied in this study is acquired from the secondary sources, namely Thomson Reuters Datastream 5.1.

This study has adopted the CAMEL analysis framework in evaluating the performance of public listed banks in ASEAN countries. CAMEL analysis has been a common rating system applied by the government, regulators, and researchers in measuring the bank soundness. Dang (2011) noted that the scholar often used the CAMEL framework to proxy bank specific variables. These variables also known as the internal factors, which are under the control of the bank to manipulate and it is different for each bank. Based on Ongore and Kusa (2013), these factors include size of capital, composition of credit portfolio, management quality, interest rate policy, state of information technology, labor productivity, ownership, risk level, bank size, and etc.

Through CAMEL analysis, the financial performance of banks can be evaluated based on five perspectives. These include the Capital adequacy, Assets quality, Management efficiency, Earning quality and Liquidity. The choice of ratios for each element is based on the study of Apsal and Malhotra (2012) and Dang (2011).

According to Prasad and Ravinder (2012), capital adequacy refers to the banks' overall financial condition and the management ability to meet the need of additional capital. Assets quality is a measure to determine the components of non-performing loans to total assets. The management efficiency reflects the effectiveness and efficiency of management. However, earning quality indicates the bank's ability to have a constant earning. The liquidity measure ensures the percentage of funds from depositors is invested in securities with high returns and generates profit to increase the liquidity provision for depositors.

Capital adequacy could be measured by capital adequacy ratio (CAR), Debt to Equity Ratio (D/E), and Advance to Assets Ratio (Adv/Ast). CAR measures capital position of bank. It is a ratio obtained by computing the total capital over total assets, which determines the ability and capacity of the bank to bear the reasonable level of losses which derived from the operation. The higher ratio indicates that the bank is adequately capitalized to its operation expansion, investors are protected, and the bank is stronger. Hence, this ratio ensures that the banks must have adequate capital for their business expansion. On the other hand, Debt to equity ratio indicates the bank's leverage. It shows the portion of debt and equity used by the bank to finance its assets. Higher ratios indicate less protection for creditors, depositors, and etc. As for advance to assets ratio, it reflects the aggressiveness of bank in lending which in turn lead to better earning of profit. Higher ratio is preferred as compared to lower one.

The assets quality is another element of CAMEL which measures the bank's strength. It identifies the kinds of advances that the bank has made in order to earn the interest income as well as the types of debtors of the bank. For instance, the loans given to the high rated companies, the interest rate charged will be lower than the interest rate charged to the doubtful companies. Assets quality can be measured by total investments to total assets (TI/TA) shows the proportion of assets are used for investment as compared to advances. The higher the ratio indicates the bank is more conservative as it maintains high cushion of investment as a safeguard against NPAs. Besides that, provision for loan loss ratio indicates the amount of expense that the bank set aside for future losses on bad loans (loan defaults). A bank with low provision for loan loss ratio shows that the bank is taking a small number of risky loans. However, the bank with high provision for loan loss ratio indicates that the bank is taking higher level of risks.

Next, following the notions of Uniform Financial Institutions Rating System (1997, p. 6), management quality generally shows the ability of board members and management team to measure, identify and controls the risks of business activities as well as to make sure the efficient, safety and sound operation in order to comply with the rules and regulations. Total advances to total deposits (TA/TD) is used to examine the management efficiency in 
converting the bank deposits available excluding the other funds such as equity capital into advances to generate greater profit. Moreover, return on equity (ROE) is a ratio which reflects the profitability of the bank. It is obtained by computing the profit after-tax over total equity.

Earning quality is an important element in the CAMEL model as it determines the ability of bank to earn its profit. Besides, it identifies the future growth and sustainability of bank. In determining the earning quality, operating profit to total assets (OP/TA) is used to specify the profit that bank earned from its operations for every dollar invested in the total assets. Net profit to total asset (NP/TA) however shows the return generated on the assets used. Higer ratio is preferable as it shows the greater earning potential of bank. Besides that, interest income to total income (II/TI) is also important in determining earning quality as it shows the percentage of income bank generated from lending activities over the total income that the bank had generated during the financial year. The earning ability of bank at a given level of total assets is indicated by net interest margin to total assets (NIM/TA). Net interest margin is the difference between the interest income and interest expense.

The final element of CAMEL Analysis is liquidity, which measures the bank's ability to meet obligations. It is the most important aspect for a bank business activity since the bank faces with liquidity risk can affect their profitability as well as their image. Liquid assets to total assets (LA/TA) are the ratio that evaluates the overall bank's liquidity. Liquid assets include cash in hand, short notice, money at call, and balance with other financial institutions (local or abroad). Meanwhile, liquid assets to total deposits (LA/TD) disclose the level of liquidity available to the bank's depositors. The total deposits consist of savings deposits, term deposits, demand deposits and deposits from other banks or financial institutions.

\section{Results and Discussion}

This section provides the description statistic of the results obtained through CAMEL analysis for ASEAN banking sector and also the performance of the banking sector in each of ASEAN country.

Table 1. CAMEL Analysis on Performance of ASEAN Banking Sector

\begin{tabular}{|c|c|c|c|c|c|c|c|c|}
\hline \multirow{2}{*}{$\begin{array}{l}\text { Capital } \\
\text { Adequacy }\end{array}$} & \multicolumn{2}{|l|}{ CAR (\%) } & \multicolumn{2}{|c|}{ D/E (Times) } & \multicolumn{4}{|c|}{ Adv/Ast (\%) } \\
\hline & Avg. & Rank & Avg. & & Rank & Avg. & & Rank \\
\hline Malaysia & 12.40 & 4 & 2.212 & & 5 & 66.06 & & 2 \\
\hline Singapore & 13.53 & 3 & 1.612 & & 3 & 64.41 & & 3 \\
\hline Indonesia & 9.07 & 5 & 0.640 & & 1 & 43.66 & & 5 \\
\hline Thailand & 18.22 & 1 & 1.949 & & 4 & 77.86 & & 1 \\
\hline Philippines & 17.85 & 2 & 0.793 & & 2 & 47.58 & & 4 \\
\hline \multirow[t]{2}{*}{ Asset Quality } & \multicolumn{4}{|c|}{ TI/TA } & \multicolumn{4}{|c|}{ Prov. Loan Loss } \\
\hline & \multicolumn{2}{|c|}{ Avg. } & \multicolumn{2}{|c|}{ Rank } & \multicolumn{2}{|c|}{ Avg. } & \multicolumn{2}{|c|}{ Rank } \\
\hline Malaysia & \multicolumn{2}{|c|}{17.44} & \multicolumn{2}{|c|}{2} & \multicolumn{2}{|c|}{1.16} & \multicolumn{2}{|c|}{2} \\
\hline Singapore & \multicolumn{2}{|c|}{18.69} & \multicolumn{2}{|c|}{4} & \multicolumn{2}{|c|}{0.48} & \multicolumn{2}{|c|}{1} \\
\hline Indonesia & \multicolumn{2}{|c|}{17.83} & \multicolumn{2}{|c|}{3} & \multicolumn{2}{|c|}{1.86} & \multicolumn{2}{|c|}{4} \\
\hline Thailand & \multicolumn{2}{|c|}{15.04} & \multicolumn{2}{|c|}{1} & \multicolumn{2}{|c|}{2.01} & \multicolumn{2}{|c|}{5} \\
\hline Philippines & & & & & & & & \\
\hline Management & & & & & & $\mathrm{R}$ & & \\
\hline Efficiency & & & & & & & & \\
\hline Malaysia & & & & & & & & \\
\hline Singapore & & & & & & & & \\
\hline Indonesia & & & & & & & & \\
\hline Thailand & & & & & & & & \\
\hline Philippines & & & & & & & & \\
\hline Earning Quality & OP/TA & & NP/TA & & & & & $\overline{T A}$ \\
\hline & Avg. & & Avg. & Rank & Avg. & Rank & Avg. & Rank \\
\hline Malaysia & 1.10 & & 0.72 & 3 & 75.06 & 3 & 2.14 & 4 \\
\hline Singapore & 1.19 & & 0.94 & 2 & 78.40 & 2 & 1.73 & 5 \\
\hline Indonesia & -0.18 & & -0.48 & 5 & 66.22 & 5 & 2.83 & 2 \\
\hline Thailand & 0.12 & & -0.20 & 4 & 78.67 & 1 & 2.68 & 3 \\
\hline Philippines & 1.25 & & 1.04 & 1 & 73.26 & 4 & 3.30 & 1 \\
\hline Liquidity & LA/TA & & & & & LA & & \\
\hline & Avg. & & Rank & & & & & ink \\
\hline Malaysia & 4.62 & & 4 & & & 97 & & 4 \\
\hline Singapore & 5.74 & & 2 & & & 12 & & 2 \\
\hline Indonesia & 5.35 & & 3 & & & 33 & & 3 \\
\hline Thailand & 1.72 & & 5 & & & 8 & & 5 \\
\hline Philippines & 9.58 & & 1 & & & 28 & & 1 \\
\hline
\end{tabular}

Notes. CAR- capital adequacy ratio; D/E - debt to equity ratio; Adv/Ast - advance to assets ratio; TI/TA - total 
investments to total assets; TA/TD - total advances to total deposits; ROE- return on equity; OP/TA - operating profit to total assets; NP/TA; net profit to total assets; II/TI - interest income to total income; NIM/TA - net interest margin to total assets; LA/TA - liquid assets to total assets; LA/TD- liquid assets to total deposits

Table 2. Composite Ranking for Overall Performance

\begin{tabular}{lccccccc}
\hline Country & C & A & M & E & L & Avg. & Rank \\
\hline Malaysia & 3.67 & 2.00 & 3.25 & 3.25 & 4.00 & 3.18 & 3 \\
Singapore & 3.00 & 2.50 & 1.50 & 2.75 & 2.00 & 2.35 & 1 \\
Indonesia & 3.67 & 3.50 & 3.00 & 4.25 & 3.00 & 3.68 & 5 \\
Thailand & 2.00 & 3.00 & 3.00 & 3.00 & 5.00 & 3.20 & 4 \\
Philippines & 2.67 & 4.00 & 3.50 & 1.75 & 1.00 & 2.58 & 2 \\
\hline
\end{tabular}

Table 2 represents the overall performance of banking sectors in ASEAN countries based on CAMEL Analysis approach. The composite average obtained for the overall evaluation is based on the empirical results as shown in Table 1. Singapore appears to be the top performer with the composite average of 2.35 , followed by the Philippines with composite average of 2.58. Malaysia and Thailand obtained the third and fourth position with composite average of 3.18 and 3.20. However, Indonesia has the last position with the composite average of 3.68 . Referring to Table 1, Singapore has performed very well in terms of management efficiency with the group average of 1.50 compared to the other countries. Based on The Banker (2013), the three banks from Singapore which are DBS Group Holdings, Overseas-Chinese Banking and United Overseas Bank have dominated the top position in the ranking of ASEAN banking sector by Tier 1 capital and considerable margin.

Table 3. CAMEL Analysis on Performance of Banking Sector in Malaysia

\begin{tabular}{lccccccc}
\hline Malaysia & C & A & M & E & L & Avg. & Rank \\
\hline AMMB Holdings & 4.67 & 7.00 & 4.00 & 6.25 & 2.50 & 4.88 & 3 \\
RHB Capital & 8.00 & 5.50 & 4.50 & 7.25 & 7.50 & 6.55 & 8 \\
Public Bank & 3.67 & 3.50 & 3.00 & 1.50 & 6.00 & 3.53 & 1 \\
Malayan Banking & 8.00 & 5.00 & 4.50 & 3.00 & 1.00 & 4.30 & 2 \\
Hong Leong Financial Group & 5.00 & 4.00 & 4.00 & 7.25 & 8.00 & 5.65 & 6 \\
Hong Leong Bank & 5.00 & 2.50 & 5.50 & 4.00 & 7.50 & 4.90 & 4 \\
CIMB Group Holdings & 5.33 & 7.50 & 5.50 & 4.00 & 3.50 & 5.17 & 5 \\
BIMB Holdings & 4.67 & 9.00 & 9.00 & 8.00 & 3.00 & 6.73 & 9 \\
Alliance Financial Group & 5.00 & 2.50 & 10.00 & 6.75 & 10.00 & 6.85 & 10 \\
Affin Holdings & 5.67 & 8.50 & 5.00 & 7.00 & 6.00 & 6.43 & 7 \\
\hline
\end{tabular}

Public Bank has consistently ranked the top position in terms of capital adequacy, management efficiency, and earning quality, with the average of 3.67, 3.00, and 1.50 respectively compared to other banks in Malaysia. Overall, Public Bank is ranked the top position with the composite average of 3.53. This is followed by Malayan Banking with composite average of 4.30. Meanwhile, Alliance Financial Group is at the last position with the composite average of 6.85 .

Table 4. CAMEL Analysis on Performance of Banking Sector in Singapore

\begin{tabular}{lccccccc}
\hline Singapore & C & A & M & E & L & Avg. & Rank \\
\hline United Overseas Bank & 2.33 & 2.50 & 1.50 & 1.00 & 1.00 & 1.67 & 1 \\
Oversea-Chinese Banking & 2.33 & 1.50 & 1.50 & 2.00 & 3.00 & 2.07 & 2 \\
DBS Group Holdings & 1.33 & 2.00 & 3.00 & 3.00 & 2.00 & 2.27 & 3 \\
\hline
\end{tabular}

As for Singapore, United Overseas Bank is the top performer with the composite average of 1.67. In every sub parameters of the CAMEL Analysis component, United Overseas Bank has almost consistently achieved the group average between 1.00 to 2.50, indicating that it has performed well compared to Oversea-Chinese Banking and DBS Group Holdings. It has performed the best in Earning Quality as well as Liquidity with the group average of 1.00 . 
Table 5. CAMEL Analysis on Performance of Banking Sector in Indonesia

\begin{tabular}{|c|c|c|c|c|c|c|c|}
\hline Indonesia & $\mathbf{C}$ & $\mathbf{A}$ & M & $\mathbf{E}$ & $\mathbf{L}$ & Avg. & Rank \\
\hline BRI Agroniaga & 21.33 & 9.00 & 25.50 & 23.25 & 27.00 & 21.22 & 27 \\
\hline Bank Artha Graha International & 10.33 & 7.50 & 4.50 & 9.50 & 11.00 & 8.57 & 1 \\
\hline Bank Bukopin & 18.67 & 8.50 & 14.50 & 18.00 & 20.50 & 16.03 & 20 \\
\hline Bank Bumi Arta & 11.00 & 6.50 & 20.00 & 14.00 & 19.50 & 14.20 & 14 \\
\hline Bank Capital Indonesia & 23.00 & 8.50 & 25.50 & 21.50 & 28.00 & 21.30 & 28 \\
\hline Bank Central Asia & 13.33 & 22.0 & 12.50 & 6.25 & 5.00 & 11.82 & 7 \\
\hline Bank CIMB Niaga & 16.33 & 19.5 & 4.00 & 20.50 & 10.50 & 14.17 & 13 \\
\hline Bank ICB Bumiputera & 12.67 & 13.0 & 18.00 & 16.75 & 14.00 & 14.88 & 17 \\
\hline Bank International Indonesia & 10.33 & 24.5 & 16.50 & 17.25 & 7.00 & 15.12 & 18 \\
\hline Bank Mandiri & 16.33 & 22.5 & 13.00 & 11.00 & 15.00 & 15.57 & 19 \\
\hline Bank Mayapada Internasional & 8.00 & 6.50 & 13.00 & 16.50 & 17.50 & 12.30 & 8 \\
\hline Bank Mega & 19.33 & 17.5 & 9.50 & 9.00 & 2.00 & 11.47 & 4 \\
\hline Bank Negara Indonesia & 9.00 & 25.5 & 7.50 & 20.00 & 4.50 & 13.30 & 10 \\
\hline Bank Nusantara Parahyangan & 12.33 & 14.5 & 11.50 & 12.50 & 15.00 & 13.17 & 9 \\
\hline Bank OCBC NISP & 11.00 & 15.5 & 8.50 & 9.25 & 13.50 & 11.55 & 5 \\
\hline Bank of India Indonesia & 7.00 & 10.0 & 12.50 & 5.75 & 8.50 & 8.75 & 2 \\
\hline Bank Pan Indonesia & 9.67 & 22.0 & 7.50 & 3.50 & 16.00 & 11.73 & 6 \\
\hline Bank Permata & 12.00 & 22.0 & 12.00 & 17.25 & 7.00 & 14.05 & 12 \\
\hline Bank Pundi Indonesia & 12.67 & 15.5 & 19.00 & 15.00 & 7.00 & 13.83 & 11 \\
\hline Bank QNB Kesawan & 12.33 & 15.5 & 19.50 & 18.25 & 17.50 & 16.62 & 22 \\
\hline Bank Rakyat Indonesia & 12.67 & 18.5 & 6.50 & 4.25 & 2.00 & 8.78 & 3 \\
\hline Bank Sinarmas & 22.00 & 4.50 & 24.50 & 22.50 & 24.00 & 19.50 & 26 \\
\hline Bank Tabungan Pensiunan Nasional & 18.67 & 7.00 & 21.50 & 13.00 & 26.00 & 17.23 & 23 \\
\hline Bank Victoria International & 19.33 & 23.5 & 17.00 & 16.75 & 11.00 & 17.52 & 24 \\
\hline Bank Windu Kentjana & 17.67 & 7.50 & 23.00 & 15.75 & 25.00 & 17.78 & 25 \\
\hline Bank Danamon Indonesia & 16.67 & 26.0 & 3.50 & 19.50 & 7.00 & 14.53 & 15 \\
\hline Bank Ekonomi Raharja & 15.67 & 8.50 & 18.50 & 17.25 & 22.00 & 16.38 & 21 \\
\hline Bank Himpunan Saudara 1906 & 16.67 & 4.50 & 17.00 & 12.00 & 23.00 & 14.63 & 16 \\
\hline
\end{tabular}

Based on the composite average result, Bank Artha Graha is ranked the first position out of 28 banks evaluated in Indonesia. Although it has never been ranked the top position in any of the CAMEL indicators, but it has consistently achieved good performance in every sub-parameter of each indicator, which resulted the composite average of 8.57. Bank of India Indonesia is then ranked second with the composite average of 8.75. However, Bank Capital Indonesia is the least performer with the highest composite average of 21.30 that reflects poor performance in every CAMEL indicator.

Table 6. CAMEL Analysis on Performance of Banking Sector in Thailand

\begin{tabular}{lccccccc}
\hline Thailand & C & A & M & E & L & Avg. & Rank \\
\hline TMB Bank & 4.67 & 6.00 & 7.00 & 7.75 & 6.00 & 6.28 & 8 \\
Tisco Financial Group & 5.00 & 6.00 & 4.50 & 3.75 & 3.50 & 4.55 & 4 \\
Thanachart Capital & 6.00 & 8.50 & 1.50 & 7.25 & 9.50 & 6.55 & 9 \\
Siam Commercial Bank & 4.67 & 5.50 & 7.50 & 4.50 & 5.00 & 5.43 & 5 \\
Krung Thai Bank & 4.33 & 3.50 & 5.00 & 5.50 & 9.00 & 5.47 & 6 \\
Kiatnakin Bank & 5.00 & 5.00 & 2.00 & 2.00 & 6.50 & 4.10 & 2 \\
Kasikornbank & 4.33 & 4.00 & 5.50 & 4.75 & 2.50 & 4.22 & 3 \\
CIMB Thai Bank & 9.67 & 9.00 & 10.00 & 8.00 & 7.50 & 8.83 & 10 \\
Bank of Ayudhya & 3.67 & 2.50 & 5.00 & 5.75 & 1.50 & 3.68 & 1 \\
Bangkok Bank & 7.67 & 5.00 & 7.00 & 5.75 & 4.00 & 5.88 & 7 \\
\hline
\end{tabular}

As seen in the above table, Bank Ayudhya is ranked the first in Thailand with the composite average of 3.68. The result indicates that Bank Ayudhya has performed relatively well in its capital adequacy; asset quality and liquidity which group average are $3.67,2.50$, and 1.50 respectively. In contrary, CIMB Thai Bank is ranked the last, with the composite average of 8.83 . 
Table 7. CAMEL Analysis on Performance of Banking Sector in the Philippines

\begin{tabular}{lccccccc}
\hline Philippines & C & A & M & E & L & Avg. & Rank \\
\hline Bank of The Philippines Islands & 6.67 & 7.50 & 6.50 & 4.00 & 2.50 & 5.43 & 4 \\
BDO Unibank & 9.67 & 3.00 & 10.00 & 10.50 & 10.50 & 8.73 & 10 \\
China Banking & 4.67 & 10.50 & 4.50 & 3.25 & 8.50 & 6.28 & 9 \\
Citystate Savings & 3.33 & 1.00 & 6.50 & 8.50 & 12.00 & 6.27 & 7 \\
Metropolitan Bank & 5.33 & 6.50 & 7.00 & 7.00 & 5.50 & 6.27 & 7 \\
Philippine National Bank & 8.00 & 9.00 & 10.50 & 11.50 & 7.00 & 9.20 & 11 \\
Philippine Savings Bank & 4.67 & 4.50 & 5.50 & 3.75 & 10.50 & 5.78 & 5 \\
Philippines Bank of & 10.67 & 7.50 & 10.50 & 9.75 & 8.50 & 9.38 & 12 \\
Communications & & & & & & & \\
Philtrust Bank & 7.00 & 5.00 & 7.50 & 4.25 & 1.00 & 4.95 & 2 \\
Rizal Commercial Banking & 6.67 & 6.50 & 5.00 & 7.50 & 4.00 & 5.93 & 6 \\
Security Bank & 5.67 & 9.00 & 1.00 & 4.00 & 5.50 & 5.03 & 3 \\
Union Bank of the Philippines & 5.67 & 8.00 & 3.50 & 4.00 & 2.50 & 4.73 & 1 \\
\hline With the con
\end{tabular}

With the composite average of 4.73, Union Bank of the Philippines has been ranked the first out of 12 banks analyzed in Philippines. It is the best in earning quality for both operating to total assets and net profit to total assets ratios with $2.12 \%$ and $2.05 \%$. This is followed by Philtrust Bank with composite average of 4.95 . Philippines Bank of Communications is ranked the last position with composite average of 9.38 due to poor performance in all of the CAMEL indicators.

\section{Conclusion}

The study measures the performance of public listed banks in five major ASEAN countries; Malaysia, Singapore, Indonesia, Thailand and the Philippines. The CAMEL analysis is chosen to evaluate the bank performance based on five elements which are Capital Adequacy, Asset Quality, Management Efficiency, Earning Quality, and Liquidity. Annual data is utilized to compute performance of banks from the period of 1997 to 2011. The bank performance is measured based on two perspectives. First, the performance of banking sector in ASEAN region will be evaluated. Second, the performance of banking sector in each of the ASEAN countries will be examined.

The results of the CAMEL analysis indicate that public listed banks in Singapore have the best performance comparatively to Malaysia, Indonesia, Thailand, and the Philippines. To sum up, Thailand's public listed banks have the best performance in capital adequacy, Malaysia's public listed banks has the best performance in asset quality, Singapore's public listed banks has the best performance in management efficiency, while the Philippines' public listed banks has the best performance in both earning quality and liquidity based on the indicators of CAMEL. It is identified that Public Bank in Malaysia, United Overseas Bank in Singapore, Bank Artha Graha in Indonesia, Bank of Ayudhya in Thailand and Union Bank of the Philippines in the Philippines as the public listed banks with best performance by country through the comprehensive results. The results of the study are important as the emerging economies in ASEAN countries will attract both local and global investment banks to invest and strengthen their financial position in the ASEAN region. Hence, the banking performance of the country in this region as compares to its counterparts is relatively important with the increasing of contestable international market.

\section{Acknowledgements}

Financial support from MyRA Grant Scheme F01/SpSTG/1589/2017, Universiti Malaysia Sarawak is gratefully acknowledged. All remaining flaws are the responsibilities of the authors.

\section{References}

ASEAN Bankers Association. (2012). About ABA-Overview. Retrieved December 24, 2012, from http://www.aseanbankers.org/about/index.htm

ASEAN Studies Centre. (2010). The Global Economic Crisis: Implications for ASEAN (No. 10). Institute of Southeast Asian Studies.

Aspal, P., \& Malhotra, N. (2012). Performance Appraisal of Indian Public Sector Banks. In Proceedings of 19th International Business Research Conference.

Barry, T. A., Dacanay, S. J. III, Lapetit, L., \& Tarazi, A. (2010). Ownership Structure and Bank Efficiency in Six Asian Countries. Philippine Management Review (Special Issue), 18, 19-35.

Besar, D. S. (2011). Essays on Indonesian Banking: Competition, Efficiency, and its Role in Monetary Policy Transmission. (Unpublished Doctoral thesis, City University London)

Bhatawdekar, S (2010). Financial Ratios and Financial Ratio Analysis. Retrieved January 23, 2013, from 
http://shyam.bhatawdekar.net/index.php/2010/01/13/financial-ratios-and-financial-ratio-analysis/

Bonin, J. P., Hasan, I., \& Wachtel, P. (2005). Bank performance, efficiency and ownership in transition countries. Journal of Banking \& Finance, 29, 31-53. https://doi.org/10.1016/j.jbankfin.2004.06.015

Chan, S. G., \& Karim, M. Z. A. (2011). Efficiency of foreign banks: Evidence from selected (Association of Southeast Asian Nations) ASEAN countries. African Journal of Business Management, 5(14), 5617-5626.

Claessens, S., Demirgüç-Kunt, A., \& Huizinga, H. (2001). How does foreign entry affect domestic banking market? Journal of Banking and Finance, 25, 891-911. https://doi.org/10.1016/S0378-4266(00)00102-3

Dang, U. (2011). The CAMEL Rating System in Banking Supervision: A Case Study, dissertation, Arcada University of Applied Sciences, International Business.

Datastream. (2013) Thomson Reuters Datastream. [Online]. Available at: Subscription Service (Accessed: April 2013).

Echchabi, A. (2013). Financial development and economic growth nexus in ASEAN-5 countries: A critical review. PhD paper, Department of Business Administration, Faculty of Economics and Management Sciences, International Islamic University Malaysia.

Fries, S., \&Taci, A. (2002). Banking reform and development in transition economic. (EBRD Working Papers 71). London: European Bank for Reconstruction and Development (EBRD), Office of the Chief Economist.

Garcia, G. (1997). A framework for analysis and assessment. In W.E. Alexander, J. M. Davis, L.P. Ebrill \& C. J. Lingren (Eds.), Systematic bank restructuring and macroeconomy policy. Washington, DC: International Monetary Fund.

Halkos, G. E., \& Salamouris, D. S. (2004). Efficiency measurement of the Greek commercial banks with the use of financial ratios: a data envelopment analysis approach. Management Accounting Research, 15(2), 201-224. https://doi.org/10.1016/j.mar.2004.02.001

Hassan, M. K., \& Bashir, A. H. M. (2003). Determinants of Islamic banking profitability. Paper presented at the $10^{\text {th }}$ ERF Annual Conference, Marrakesh, Morocco.

Huang, Y. T., Wen, S. Y., \& Yu, J. (2012). Financial Determinants of Bank Performance in Taiwan. Journal of Economics and Behavioural Studies, 4(12), 691-702.

Jha, S., \& Hui, X. (2012). A comparison of financial performance of commercial banks: A case study of Nepal. African Journal of Business Management, 6(25), 7601-7611.

Johnes, J., Izzeldin, M., \& Pappas, V. (2009). The efficiency of Islamic and conventional banks in the Gulf Cooperation Council (GCC) countries: An analysis using financial ratios and data envelopment analysis. Lancaster University Management School, Working paper 2009/023

Karim, M. Z. A. (2001). Comparative bank efficiency across select ASEAN countries. ASEAN Economic Bulletin, 289-304. https://doi.org/10.1355/AE18-3D

Khan, M., \& Jain, P. (2007), Financial Management: Text, Problems and Cases, fifth edition, Tata McGraw-Hill.

Kumar, S., \& Gulati, R. (2008). An examination of technical, pure technical, and scale efficiencies in Indian public sector banks using data envelopment analysis. Eurasian Journal of Business and Economics, 1(2), 33-69.

Mongid, A., Tahir, I. M., \& Haron, S. (2012). The Relationship between Inefficiency, Risk and Capital: Evidence from Commercial Banks in ASEAN. Journal of Economics and Management, 6(1), 58-74.

Mugume, A. (2007). Market Structure and Performance in Uganda's Banking Industry. Paper presented to the African Econometrics Society, Cape Town available at http://www.africametrics.org/documents/conference07/Day\%202/Session\%206/Mugume\%20market\%20str utcure.pdf

Nimalathasan, B. (2008). A Comparative Study of Financial Performance of Banking Sector in Bangladesh - An Application of CAMELS Rating System. Annals of University of Bucharest, Economic and Administrative Series, 2, 141-152.

Ongore, V. O., \& Kusa, G. B. (2013). Determinants of Financial Performance of Commercial Banks in Kenya. International Journal of Economics and Financial Issues, 3(1), 237-252.

Phar, K. B. (2010). The Banking Industry in ASEAN on the Verge of Higher Growth. Retrieved October 5, 2012, 
from http://cariasean.org/view/The_Banking_Industry_in_ASEAN_on_the_Verge_of_Higher_Growth

Prasad, K. V. N. (2012). Evaluating performance of public and private sector banks through camel model. Asian Journal of Research in Banking and Finance, 2(3), 36-46.

Prasad, K. V. N., \& Ravinder, G. (2012). A Camel Model Analysis of Nationalized Banks in India. International Journal of Trade and Commerce, 1(1), 23-33.

Reddy, K. S. (2012). Relative Performance of Commercial Banks In India Using The CAMEL Approach. International Journal of Multidisciplinary, 2(3).

Said, R. M., \& Tumin, M. H. (2011). Performance and Financial Ratios of Commercial Banks in Malaysia and China. International Review of Business Research Papers, 7(2), 157-169.

Sufian, F., \& Habibullah, M. S. (2009). The Asean-4 Banking Sectors. Bulletin of Monetary Economics and Banking.

Tahir, I. M. (1999). Market structure and efficiency in ASEAN banking. Unpublished doctoral thesis. The University of Wales, Bangor.

Tahir, I. M., Mongid, A., \& Haron, S. (2012). The Determinants of Bank Cost Inefficiency in ASEAN Banking. Jurnal Pengurusan, 36, 69-76.

The Banker. (2013). Top ASEAN banks: Inching in on Singapore's lead. Retrieved June 27, 2013, from http://www.thebanker.com/Banker-Data/Banker-Rankings/Top-Asean-banks-inching-in-on-Singapore-s-lea d

Uniform Financial Institutions Rating System. (1997). Statements of Policy. The United States: Federal Deposit Insurance Corporation (FDIC).

Wyman, O. (2012). The Future of Asian Banking- Volume 2. Retrieved June 4, 2013, from http://www.oliverwyman.com/media/Future_of_Asian_Banking_Volume_2.pdf

\section{Copyrights}

Copyright for this article is retained by the author(s), with first publication rights granted to the journal.

This is an open-access article distributed under the terms and conditions of the Creative Commons Attribution license (http://creativecommons.org/licenses/by/4.0/). 